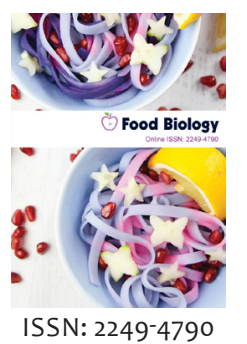

Received: December 19, 2018 Accepted: January 21, 2019 Published: January 22, 2019

*Corresponding Author: S. Verruck

Email: silvani.verruck@gmail. com

\section{Survival of Bifidobacterium ssp. during gastrointestinal passage and their mechanism of action for pathogenic bacteria inhibition in the gut: A concise review}

\author{
S. Verruck*, E. S. Prudencio \\ Federal University of Santa Catarina, Department of Food Science and Technology, Rod. Admar Gonzaga, 1346, \\ Itacorubi, 88034-001, Florianópolis, SC, Brazil
}

\section{ABSTRACT}

Bifidobacteria genus stands out for being one of the most used probiotic bacteria for food applications. This review presents a concise and direct picture of current knowledge on bifidobacteria strains survival during the passage through the human gastrointestinal system. It also provides the necessary theoretical background and details about mechanisms of actions of bifidobacteria against pathogenic bacteria. We will also report some of the factors which make the combination of food and bifidobacteria one of the most promising research topics in the field of modern food science.

KEYWORDS: Bifidobacteria, gastrointestinal system, food pathogens inhibition, action mechanisms

\section{INTRODUCTION}

The beneficial effect of functional food and some of its components on the consumer health have been studied $[1,2]$. The primary objective of functional foods is to improve, maintain and enhance the health of consumers through the alimentation [3]. Among the foods with functional claims are those added with probiotic microorganisms [4]. Probiotics are live microorganisms that when continuously administered in adequate amounts, confer benefits to the health of the consumer [5]. The main action mechanisms of probiotics include competition for sites of adhesion, antimicrobial activity, neutralization of undesirable compounds [enterotoxins, ammonia, toxic biogenic amines], alteration of metabolism [aid in digestion, reduction of precarcinogenic enzymes], and increase of immunity [increased lymphocyte and macrophage activity] [6]. However, it is important to emphasize that these mechanisms of action attributed to the probiotics are species-specific, i.e., the same strain cannot be able to exert all these health benefits simultaneously $[4,7,8]$. In this sense, bifidobacteria stands out for being one of the majority members of the Actinobacteria class that inhabit the human gut [9]. Due to this characteristic, bifidobacteria strains are chosen for to be used in a wide range of food products in order to be delivered in the gut and, thus, exert their beneficial effects [4].

One of the significant challenges in developing a probiotic product with Bifidobacterium is to ensure a high survival rate of the bacteria during the passage through the human gastrointestinal tract $[4,10,11]$. The main obstacles for bifidobacteria are the extreme acid $\mathrm{pH}$ in the stomach and the high bile salt concentrations presence from the duodenum to the ileum [12]. However, these class of bacteria has the intrinsical advantage to accommodate their enzymatic machinery to survive along the passage through the gastrointestinal system [13]. In this way, due to this adaptive capacity, the bifidobacteria can change some metabolic/functional routs which causes an improved capacity to survive and colonize the gut [13].

When Bifidobacterium ssp. arrives alive until the large intestine, the probiotic bacteria present several mechanisms of action to adhere to the epithelium and also inhibit bacterial pathogens [14]. The mechanisms involved in this antibacterial activity is the ability of bifidobacteria to product inhibitory substances, inhibit the pathogen adhesion to surfaces and produce iron-siderophore [15]. Bifidobacterium spp. produce 
some inhibitory substances such as bacteriocins, hydrogen peroxide, and lactic and acetic acids that are effective in inhibiting the growth of several pathogenic bacteria [16]. Therefore, another important factor that influence the greatly ability of bifidobacteria strains to inhibit the pathogens is their adherence to the intestinal mucosal surface and consequently the colonization of the gut [17]. The iron-siderophore production, used for the uptake of lactoferrin or transferrin by microorganisms, is also a mechanism to inhibit the survival of pathogenic bacteria [18]. Thus, the main goal of this work is to provide an overview of the current developments of bifidobacteria specific characteristics of survive passage through the gastrointestinal system and inhibit pathogenic bacteria in the intestine.

\section{BIFIDOBACTERIA AS PROBIOTIC}

Specific criteria are used in order to select a microorganism to be used as probiotic. These bacteria must be acid and bile tolerant, nonpathogenic, no transferable antibiotic resistance and present in the normal healthy gut microbiota. Also, they could produce some antimicrobial substances against pathogenic bacteria, be genetically stable (identified by appropriate molecular techniques) and adhere to intestinal mucosa (mucus and enterocytes) [19]. Moreover, one of the most important safety aspects of the use of probiotics includes a history of being nonpathogenic and a history of no association with diseases [20]. The bioavailability of nutrients, the production of antimicrobial compounds, improvement of motility, relieving of intestinal constipation as well the decrease of Helicobacter pylori infection in the stomach are also attributed to the consumption of probiotic bacteria $[21,22]$.

In food products, one of the most used probiotic cultures is those of the genus Bifidobacterium [23-25]. Microorganisms of the genus Bifidobacterium are gram-positive, non-spore forming bacilli, without motility, catalase negative, and some strains develop branches morphologically appearing with bifidopartide form [26,27]. Most bifidobacteria survives only in anoxic conditions, however, some species can survive in aerobic conditions or tolerate oxygen in the carbon dioxide presence [28]. Bifidobacterium can grow in the temperature range of $25-45^{\circ} \mathrm{C}$, with the optimum temperature between 36 and $38{ }^{\circ} \mathrm{C}$ for growth of human origin Bifidobacterium. Bifidobacteria are demanding in relation to the $\mathrm{pH}$ values, which are around 6.5-7.0, with no growth below 4.5 or above 8.5 [22]. Most Bifidobacterium species produce vitamins such as thiamine (B1), riboflavin (B2), pyridoxine (B6), folic acid (B9), cobalamin (B12), ascorbic acid (C), nicotinic acid (PP) and biotin [29]. The principal strains of Bifidobacterium used for commercial purpose or studied in vitro and humans are summarized in Table 1.

For the beneficial effects associated with probiotic consumption to be achieved, these should be in appropriate quantities in the food and must be consumed daily [4]. Therefore, the recommended minimum daily intake is around 8-9 log Colony Forming Units (CFU g ${ }^{-1}$ or $\mathrm{mL}^{-1}$ ), which can be achieved with daily consumption of at least $100 \mathrm{~g}$ of a 6-7 log Colony Forming
Units (CFU g-1 or $\mathrm{mL}^{-1}$ of the product) [24]. Compensation for possible losses during food processing and storage as well as loss during passage through the gastrointestinal tract may directly influence this count [30]. However, factors such as high levels of oxygen, $\mathrm{pH}$, acidity, time and temperature of storage and processing cause sensitivity and directly affect the viability of bifidobacteria [31,32].

\section{TOLERANCE OF BIFIDOBACTERIA TO GASTROINTESTINAL CONDITIONS}

In order to exert the beneficial effects on the host, it is necessary that the probiotic microorganisms can overcome intact the human digestive system [27]. Since the effects of probiotics are related to their activity in the digestive tract, and these depend on their colonization and survival in this environment, these bacteria must be resistant to the physiological and physicochemical processes of the gastrointestinal system. For Naidu et al. [33], probiotic bacteria must survive passage

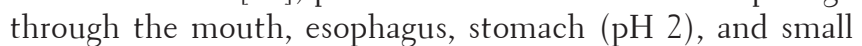
intestine to exert their benefits in the gut. Thus, they should be able to survive through gastric juice (hydrochloric acid), pancreatic juice and bile salts, i.e. surviving in acidic (stomach) and basic (duodenum) conditions [34].

Several stress conditions influenced the survival of probiotics during the passage through the gastrointestinal system [35]. Although the loss of bacterial viability occurs throughout all the digestive process, the greater losses are reported to the stomach, due to its acidity, and the presence of bile salts in the duodenum [36]. In the stomach, many strains of Bifidobacterium ssp. intrinsically lack the ability to survive such acidity. In general, the acid tolerance of bifidobacteria may be considered weak, except Bifidobacterium lactis and Bifidobacterium animalis [37]. Sánchez et al. [38] reported that the survival of bacteria lacking a respiratory chain, such as Bifidobacterium BB-12, is associated with their $\mathrm{F}_{0} \mathrm{~F}_{1}$-ATPase enzyme ability to maintain the intracellular $\mathrm{pH}$ under acidic conditions. Due to the damaging effects, even if probiotics are still viable in the stomach, upon reaching the colon, they may be in a sub-lethally injured state. Thus, their chances of survival may be compromised, along with their ability to colonize the intestine and have an advantageous effect on the host [35]. This behavior can be attributed to the low $\mathrm{pH}$ value in the stomach $(\sim 2)$ and the presence of pepsin [39,40]. Also, Matsumoto et al. [37] affirm that the acid tolerance of probiotic bacteria depends on factors such as growth medium, incubation conditions, enzymes profile and cytoplasmic membrane composition of each strain.

After exposure to the stomach conditions, the probiotic bacteria reaches to the small intestine and are submitted to the duodenum (i.e., bile salts, pancreatin and $\mathrm{pH}$ approx. 5.0) up to the ileum conditions [41]. The bile salts are known for their antimicrobial activity against probiotic bacteria, mainly due to their amphiphilic nature and ability to dissolve the bacterial cellular membrane [42]. Also, Kurdi et al. [43] observed that the bile salts cumulate in the bacterial cytoplasm, causing disturbs on membrane integrity and therefore the cell death. As observed 
Table 1: Probiotic Bifidobacterium strains used in commercial products or studied in vitro and humans.

\begin{tabular}{|c|c|}
\hline Strain & Benefits \\
\hline B. breve NCIMB8807 & $\begin{array}{l}\text { Reduces symptoms of irritable bowel syndrome, reduces gastrointestinal cancer possibilities, eradication of Campylobacter jejuni } \\
\text { in children }\end{array}$ \\
\hline B. longum BB536 & Enhance intestinal function in premature infants $>1000 \mathrm{~g}$ \\
\hline B. longum BL04-3008 & Decrease of azoxymethane with reduction of gastrointestinal cancer possibilities \\
\hline B. lactis DR 10 & Reduction of $E$. coli in the gastrointestinal tract \\
\hline B. animalis spp. lactis BB 12 & $\begin{array}{l}\text { Prevention of traveler's diarrhea, treatment of viral diarrhea including rotavirus diarrhea, modulation of intestinal flora, } \\
\text { improvement of constipation, modulation of immune response, atopic dermatitis symptoms alleviation in children }\end{array}$ \\
\hline B. animalis DN-173010 & Increase bowel motility and reduce diarrhea caused by rotavirus \\
\hline
\end{tabular}

Adapted from Lerayer et al.[6] and Saarela et al. [20].

by Vinderola and Reinheimer [44], the survival of probiotic in bile environment depends on the concentration of bile, exposure time and bacterial species and strains. Moreover, the survival of probiotic strains in the gastrointestinal tract might not only depend on their number and physiological state but also on the food matrix and food consumption habits that affect bile excretion [45]. Aspects such as amount and type of protein and fat, $\mathrm{pH}$, presence of specific carbohydrates or other ingredients may also influence the resistance of probiotics during passage through the gastrointestinal tract [46-49]. Begley et al. [50] also stated that some components of the food might bind to bile salts, which would protect the probiotic bacteria from their toxicity.

After passage through the stages of the stomach and duodenum, another essential aspect about probiotic bacteria is their ability to adhere to the epithelial surface and colonize the small intestine or colon [51]. The hydrophobic bacterial surface is essential for the interaction between the intestinal glycoprotein layer, the receptor on the intestinal epithelial cell and fatty acid binding sites [52]. Also, the presence of prevailing apolar groups of bifidobacteria membrane may also support the cell adherence. As observed by Wang et al. [53], the surface hydrophobicity of $\mathrm{B}$. animalis BB-12 was $50 \%$. However, the adhesion ability varies with the type of Bifidobacterium, strain and the previous damages suffered [51]. Also, it must be highlighted that Lee et al. [54] showed for an inflammatory bowel disease that the better efficacy of the treatment was strongly dependent by using milk as a carrier medium. Their results strongly indicate that dairy products might be the preferred delivery matrix for probiotic strains for benefiting human health.

In light of these observations, to evaluate the survival of probiotics during and after the ingestion process, in vitro gastrointestinal simulation methodologies are being used as a rapid and straightforward approach in place of in vivo assays, since the latter are expensive long-term studies with high variability between individuals [55]. In vitro studies can provide useful insights on probiotic action, safety, and efficacy of probiotics targeted for human use [45]. Several studies have conducted in vitro gastrointestinal trials and evaluated the survival of probiotics in foods [34,46,48,56-59], but not continuously as naturally occurs during digestion. For that reason, evaluation of gastrointestinal tolerance by these methods may not satisfactory predict the in vivo survivability of probiotics accompanied by the food matrix [60]. Thus, Madureira et al. [42] recommend the use of a continuous in vitro gastrointestinal model that includes all compartments of the gastrointestinal tract (mouth, esophagus-stomach, duodenum, and ileum). This method also includes the presence of enzymes $(\alpha$-amylase, pepsin, and pancreatin) and bile salts, mechanical simulation of peristaltic movements, time retention and also a $\mathrm{pH}$ gradient in the stomach. By using this methodology, Verruck et al. [39] verified the protective effect of a buffalo Minas fresh cheese on Bifidobacterium BB-12 survival. Pinto et al. [61] using spray drying method, verified that the use of sweet whey and inulin as encapsulating agents provided better protection to the bifidobacteria when compared with the free cells after exposure to these simulated gastrointestinal conditions. Holkem et al. [32] demonstrated that Bifidobacterium BB-12 resists better to the passage through simulated gastrointestinal fluids and under acid conditions when the technique of emulsification/internal ionic gelation for encapsulation was used. This in vitro simulated gastrointestinal conditions protocol was also successfully used by Almeida et al. [62], Pinto et al. [63] and Verruck et al. [40] for probiotic mascarpone-type cheese, greek yogurt, and microcapsules with full-fat goat's milk and prebiotics, respectively. Therefore, extrapolation of data from closely related strains is not acceptable, thus, each product and strain should be tested and documented independently [45]. So, the protocol proposed by Madureira et al. [42] may be used, giving us a safe view of what happens to the probiotic bacteria viability after the passage through the gastrointestinal system.

\section{MECHANISMS OF ACTION OF PROBIOTICS FOR PATHOGENIC BACTERIA INHIBITION}

The gastrointestinal tract is one of the access ways of pathogens, and if the defense mechanisms fail, these pathogens can colonize and/or penetrate the cells and tissues of the host [64]. As summarized in Figure 1, probiotic can inhibit the growth of pathogenic bacteria in the gut by several mechanisms, such as the capacity to synthesize antibacterial substances, inhibit the adhesion of pathogenic bacteria on the intestinal surface and also produce iron-siderophores [15]. Siró [45] reported that probiotics, such as Lactobacillus spp. and Bifidobacterium spp., have developed different mechanisms to survive in competition with pathogenic bacteria. In the case of Bifidobacterium spp., one of their important proprieties is the ability to produce organic acids (e.g., lactic and acetic acids), hydrogen peroxide and bacteriocins to suppress the colonization of pathogenic bacteria in the gut [22]. Makras and De Vuyst [65] tested 37 Bifidobacterium strains, including Bifidobacterium animalis subsp. lactis $\mathrm{BB} 12$, and reported a great organic acids production 


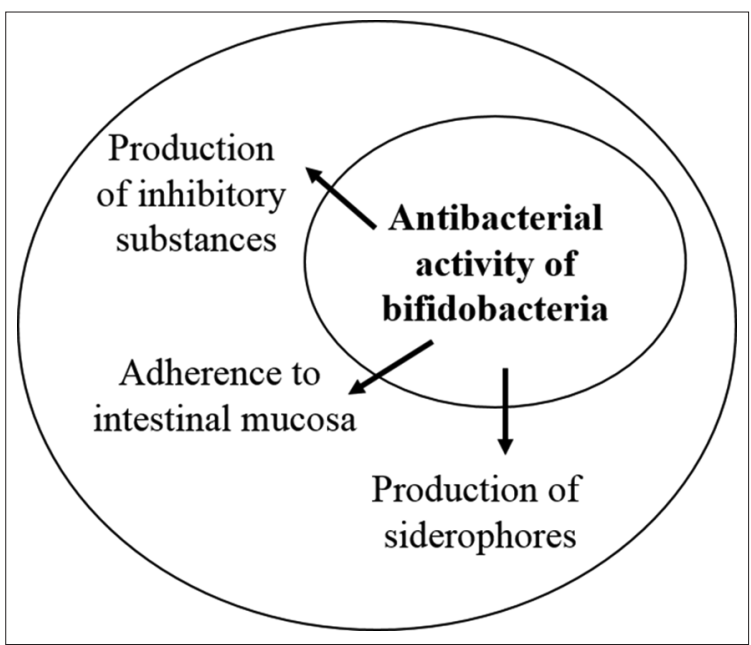

Figure 1: Summary of antibacterial activities of bifidobacteria. Adapted and modified from Fung et al.[15]

with a decrease in the medium $\mathrm{pH}$. This behavior led to the inhibition of Salmonella enterica ser. Typhimurium SL1344 and Escherichia coli $\mathrm{Cl} 845$.

Although the antimicrobial effect of the Bifidobacterium is often ascribed to the inhibitory action of organic acids and the related $\mathrm{pH}$ decrease in the bowel, the bifidobacteria has a high potential as bacteriocins producers [66]. Bacteriocins are ribosomallysynthesized peptides that have antimicrobial activity against other bacteria by creating pores in the cellular membrane causing the dissipation of proton motive force, ATP depletion, and leakage of nutrients that subsequently lead to cell damage or cell death [67]. Fung et al. [15] stated that numerous genera of pathogenic and nonpathogenic bacteria might be affected by bacteriocins. However, as cited by Lima et al. [68], the efficacy of probiotic bacteria against pathogens is based on a combination of bacteriocin action and production of antimicrobial substances such as hydrogen peroxide and organic acids. The antagonistic activity of Bifidobacterium lactis BB12 and Bifidobacterium longum 46 against six target pathogens was evaluated using different assays (liquid and solid media, microaerobic and anaerobic cultivation) and high activity against Shigella sonnei and E. coli was reported [69]. Gibson and Wang [70] reported that bactericidal or bacteriostatic substances were excreted by eight strains of bifidobacteria and could inhibit the growth of Salmonella spp., E. coli, Listeria monocytogenes, Campylobacter spp., S. sonnei and Vibrio cholerae. Martins et al. [71] reported production of antagonistic substances by Bifidobacterium BB12 against Bacillus cereus, Clostridium difficile, Clostridium perfringens Type A, E. coli ATCC 4328, Enterococcus faecalis, L. monocytogenes, Pseudomonas aeruginosa, S. Typhimurium, Salmonella Typhi, Shigella flexneri, S. sonnei, and Candida albicans. The better ability to colonize the gastrointestinal tract of mice is linked to higher hydrophobic property of the cell wall of Bifidobacterium BB12. Also, Saleh and El-Sayed [72] reported two bacteriocins: bifilact Bb- 12 and bifilong Bb-46, the first produced by Bifidobacterium lactis Bb-12 and the second by B. longum Bb-46. These bacteriocins shown strong activity against Staphylococcus aureus, S. Typhimurium, Bacillus cereus and E. coli.
As the colonization of the gastrointestinal tract is based on the ability of the bacteria to adhere to the intestinal epithelium, another vital factor in the competitive exclusion of pathogenic bacteria is the ability of the probiotics to adhere to the mucosal surface [20]. Collado et al. [73] reported in an in vitro study that Bifidobacterium BB-12 was able to adhere to the intestinal mucosa and inhibit several pathogens, such as Bacteroides vulgatus, Clostridium histolyticum, C. difficile, Enterobacter aerogenes, L. monocytogenes, S. Typhimurium, and S. aureus. Bernet et al. [74] reported that bifidobacteria isolated from human gastrointestinal tract were able to adhere to Caco-2 cells due to the presence of a proteinaceous adhesion-promoting factor which affected the adherence of pathogenic E. coli and S. Typhimurium. In another study, Collado et al. [75] investigated the protective effect of Bifidobacterium lactis Bbl2 and Lactobacillus rhamnosus LGG alone and in combination on the adhesion of $S$. Typhimurium, C. perfringens, C. difficile, and E. coli K2. They demonstrated that in combination, the probiotic strains enhanced each other's adhesion, mainly in pig large intestinal mucus and reduced the adhesion of all the tested pathogens. Additionally, Jungersen et al. [7] affirmed that Bifidobacterium BB-12 is able to compete for mucosal adhesion and, thus, inhibit serious gastrointestinal pathogens by antimicrobial substances production.

Beyond the capacity of producing antimicrobial substances and inhibit the adhesion of pathogenic bacteria, the production of iron-siderophores was also reported as an antimicrobial ability of probiotics [15]. In general, the iron plays a vital role in the metabolism of bacteria that requires iron for growth acting as a global regulator of gene expression [76]. To obtain the necessary iron to survive, bacteria developed several metabolic routes to excel over other lineages. One of their approach is to synthesize and export siderophores, which are chelators with high-affinity to iron [77]. Certain bacteria or fungi produce and release siderophores to scavenge extracellular iron and redeliver the metal to the cell [78]. Vazquez-Gutierrez et al. [79] evaluated the siderophore production of 86 bifidobacteria strains (30 from culture collections and 56 isolates from infants) and reported that 35 strains exhibited high siderophore activity, 31 showing intermediate and 20 low activity. They conclude that the mechanisms used by bifidobacteria to sequestrate and use iron confers an great advantage to their survival and competition agaist pathogenic bacteria.

\section{CONCLUSIONS}

Bifidobacteria strains are used in a wide range of food products in order to be delivered in the gut for exert their beneficial effects.however, these strains have some obstacles to overcome, as survive through the acid $\mathrm{pH}$ in the stomach the presence of high bile salt concentrations in the intestine. However, when these bacteria arrives alive until the large intestine, several mechanisms of action to inhibit pathogenic bacteria are present, i.e., production of inhibitory substances, inhibition of the pathogen adhesion to surfaces and production of ironsiderophores. In the light of these observations, this concise review showed the necessary theoretical background and 
some details about survival during the passage through the human gastrointestinal system and mechanisms of actions of bifidobacteria against pathogenic bacteria.

\section{ACKNOWLEDGMENT}

The authors are grateful to $\mathrm{CNPq}$ [National Council for Scientific and Technological Development, Brazil] by the financial support [CNPq, 405965/2016-8], and to CAPES [Coordination of Improvement of Higher Education Personnel, Brazil - Finance code 001] by the scholarship.

\section{REFERENCES}

1. Annunziata A, Vecchio R. Functional foods development in the European market: A consumer perspective. Journal of Functional Foods. 2011;3[3]:223-8.

2. Carrillo E, Prado-Gascó V, Fiszman S, Varela P. Why buying functional foods? Understanding spending behaviour through structural equation modelling. Food Research International. 2013;50[1]:361-8.

3. Oliveira MN De, Sivieri K, Henrique J, Alegro A, Marta S, Saad I, et al. Aspectos tecnológicos de alimentos funcionais contendo probióticos. Brazilian Journal of Pharmaceutical Sciences. 2002;38[1]:1-21.

4. Tripathi MKK, Giri SKK. Probiotic functional foods: Survival of probiotics during processing and storage. Journal of Functional Foods. 2014;9[1]:225-41.

5. Hill C, Guarner F, Reid G, Gibson GR, Merenstein DJ, Pot B, et al. The International Scientific Association for Probiotics and Prebiotics consensus statement on the scope and appropriate use of the term probiotic. Nature Reviews Gastroenterology and Hepatology. 2014;11[8]:506-14.

6. Lerayer ALS, Marasca ETG, Moreno I, Vialta A. Culturas lácticas e probióticas: identificação, classificação, detecção e aplicação tecnológica. In: Oliveira MN de, editor. Tecnologia de Produtos Lácteos Funcionais. São Paulo, SP: Atheneu; 2009. p. 125-86.

7. Jungersen M, Wind A, Johansen E, Christensen J, Stuer-Lauridsen B, Eskesen D. The science behind the probiotic strain Bifidobacterium animalis subsp. lactis BB-12®. Microorganisms. 2014;2[2]:92-110.

8. Weichselbaum E. Probiotics and health: a review of the evidence. Nutrition Bulletin. 2009;34[4]:340-73.

9. Qin J, Li R, Raes J, Arumugam M, Burgdorf KS, Manichanh C, et al. A human gut microbial gene catalogue established by metagenomic sequencing. Nature. 2010;464[7285]:59-65.

10. Granato D, Branco GF, Cruz AG, Faria J de AF, Shah NP. Probiotic Dairy Products as Functional Foods. Comprehensive Reviews in Food Science and Food Safety. 2010;9[5]:455-70.

11. Zare F, Champagne CP, Simpson BK, Orsat V, Boye JI. Effect of the addition of pulse ingredients to milk on acid production by probiotic and yoghurt starter cultures. LWT - Food Science and Technology. 2012;45[2]:155-60.

12. Ruiz L, Ruas-Madiedo P, Gueimonde M, de Los Reyes-Gavilán CG, Margolles A, Sánchez B. How do bifidobacteria counteract environmental challenges? Mechanisms involved and physiological consequences. Genes and Nutrition. 2011;6[3]:307-18.

13. González-Rodríguez I, Ruiz L, Gueimonde M, Margolles A, Sánchez B. Factors involved in the colonization and survival of bifidobacteria in the gastrointestinal tract. FEMS Microbiology Letters. 2013;340[1]:1-10.

14. Corr SC, Hill C, Gahan CGM. Understanding the mechanisms by which probiotics inhibit gastrointestinal pathogens. Advances in Food and Nutrition Research. 2009;56:1-15.

15. Fung W-Y, Lye H-S, Lim T-J, Kuan C-Y, Liong and M-T. Roles of Probiotic on Gut Health. In: Liong M-T, editor. Probiotics: Biology, Genetics and Health Aspects. Berlin, Heidelberg: Springer Berlin Heidelberg; 2011. p. 139-66.

16. O'Mahony L, McCarthy J, Kelly P, Hurley G, Luo F, Chen K, et al. Lactobacillus and Bifidobacterium in irritable bowel syndrome: symptom responses and relationship to cytokine profiles. Gastroenterology. 2005; 128[3]:541-51.

17. Balcázar JL, Vendrell D, de Blas I, Ruiz-Zarzuela I, Muzquiz JL,
Girones O. Characterization of probiotic properties of lactic acid bacteria isolated from intestinal microbiota of fish. Aquaculture. 2008;278[1-4]:188-91.

18. Moon G-S. A preliminary analysis of secreted proteins from bifidobacterium pseudocatanulatum bp1 by two-dimensional gel electrophoresis. Preventive Nutrition and Food Science. 2008;13[4]:366-9.

19. Salminen S, Kenifel W, Ouwehand AC. Probiotics, Applications in Dairy Products. In: Fuquay JW, Fox PF, McSweeney PLH, editors. Encyclopedia of Dairy Sciences. $2^{\text {nd }}$ ed. London, UK: Elsevier Ltd; 2011. p. 1:412-1:419.

20. Saarela M, Mogensen G, Fondén R, Mättö J, Mattila-Sandholm T. Probiotic bacteria: Safety, functional and technological properties. Journal of Biotechnology. 2000;84[3]:197-215.

21. O'May GA, Macfarlane GT. Health Claims Associated with Probiotics. In: Tamime A, editor. Probiotic Dairy Products. Oxford, UK: Blackwell Science Ltd; 2005. p. 138-66.

22. Shah NP. Bifidobacterium spp.: Morphology and Physiology. In: Fuquay J, Fox P, McSweeney P, editors. Encyclopedia of Dairy Sciences. $2^{\text {nd }}$ ed. London, UK: Elsevier; 2011. p. 2:381-2:387.

23. Bielecka M, Biedrzycka E, Majkowska A. Selection of probiotics and prebiotics for synbiotics and confirmation of their in vivo effectiveness. Food Research International. 2002;35[2-3]:125-31.

24. Boylston TD, Vinderola CG, Ghoddusi HB, Reinheimer JA Incorporation of bifidobacteria into cheeses: Challenges and rewards. International Dairy Journal. 2004;14[5]:375-87.

25. Saad N, Delattre C, Urdaci M, Schmitter JM, Bressollier P. An overview of the last advances in probiotic and prebiotic field. LWT - Food Science and Technology. 2013;50[1]:1-16.

26. Jin Baek Y, Lee BH. Probiotics and Prebiotics as Bioactive Components in Dairy Products. In: Park YW, editor. Bioactive Components in Milk and Dairy Products. Oxford, UK: Wiley-Blackwell; 2009. p. 287-310.

27. Shah NP. Bifidobacterium spp.: Applications in Fermented Milks. In: Fuquay JW, Fox PF, McSweeney PLH, editors. Encyclopedia of Dairy Sciences. $2^{\text {nd }}$ ed. London, UK: Elsevier Ltd; 2011. p. 1:388:1:394

28. Simpson PJ, Stanton C, Fitzgerald GF, Ross RP. Intrinsic tolerance of Bifidobacterium species to heat and oxygen and surviva following spray drying and storage. Journal of Applied Microbiology. 2005;99[3]:493-501.

29. O'Connor EB, Barrett E, Fitzgerald G, Hill C, Stanton C, Ross RP. Production of vitamins, exopolysaccharides and bacteriocins by probiotic bacteria. In: Adnan Tamime, editor. Probiotic Dairy Products. Oxford, UK: Blackwell Science Ltd: 2005. p. 167-94.

30. Vasiljevic T, Shah NP. Probiotics-From Metchnikoff to bioactives International Dairy Journal. 2008;18[7]:714-28.

31. Anal AK, Singh H. Recent advances in microencapsulation of probiotics for industrial applications and targeted delivery. Trends in Food Science and Technology. 2007;18[5]:240-51.

32. Holkem AT, Raddatz GC, Nunes GL, Cichoski AJ, Jacob-Lopes E, Ferreira Grosso CR, et al. Development and characterization of alginate microcapsules containing Bifidobacterium BB-12 produced by emulsification/internal gelation followed by freeze drying. LWT - Food Science and Technology. 2016;71:302-8.

33. Naidu AS, Bidlack WR, Clemens RA. Probiotic spectra of lactic acid bacteria [LAB]. Critical Reviews in Food Science and Nutrition. 1999;39[1]:13-126.

34. Ortakci F, Broadbent JR, McManus WR, McMahon DJ. Survival of microencapsulated probiotic Lactobacillus paracasei LBC-1e during manufacture of Mozzarella cheese and simulated gastric digestion. Journal of Dairy Science. 2012;95[11]:6274-81.

35. Yeo S-K, Ewe J-A, Tham CS-C, Liong M-T. Carriers of probiotic microorganisms. In: Liong M-T, editor. Probiotics: Biology, Genetics and Health Aspects. Berlin, Heidelberg: Springer Berlin Heidelberg; 2011. p. 191-220.

36. Mainville I, Arcand Y, Farnworth ER. A dynamic model that simulates the human upper gastrointestinal tract for the study of probiotics. International Journal of Food Microbiology. 2005;99[3]:287-96.

37. Matsumoto $M$, Ohishi $H$, Benno $Y$. H+-ATPase activity in Bifidobacterium with special reference to acid tolerance. International Journal of Food Microbiology. 2004;93[1]:109-13.

38. Sánchez B, Champomier-Vergès M-C, Collado M del C, Anglade P, Baraige F, Sanz Y, et al. Low-pH adaptation and the acid tolerance response of Bifidobacterium longum biotype longum. Applied and Environmental Microbiology. 2007;73[20]:6450-9. 
39. Verruck S, Prudêncio ES, Vieira CRW, Amante ER, Amboni RD de MC. The buffalo Minas Frescal cheese as a protective matrix of Bifidobacterium BB-12 under in vitro simulated gastrointestinal conditions. LWT - Food Science and Technology. 2015;63[2]:1179-83.

40. Verruck S, de Carvalho MW, de Liz GR, Amante ER, Vieira CRW, Amboni RDDMC, et al. Survival of Bifidobacterium BB-12 microencapsulated with full-fat goat's milk and prebiotics when exposed to simulated gastrointestinal conditions and thermal treatments. Small Ruminant Research. 2017;53[February]:48-56.

41. Guerra A, Etienne-Mesmin L, Livrelli V, Denis S, BlanquetDiot S, Alric M. Relevance and challenges in modeling human gastric and small intestinal digestion. Trends in Biotechnology. 2012;30[11]:591-600

42. Madureira AR, Amorim M, Gomes AM, Pintado ME, Malcata FX. Protective effect of whey cheese matrix on probiotic strains exposed to simulated gastrointestinal conditions. Food Research International. 2011;44[1]:465-70.

43. Kurdi P, Kawanishi K, Mizutani K, Yokota A. Mechanism of growth inhibition by free bile acids in Lactobacilli and Bifidobacteria. Journal of Bacteriology. 2006;188[5]:1979-86.

44. Vinderola CG, Reinheimer JA. Lactic acid starter and probiotic bacteria: a comparative "in vitro" study of probiotic characteristics and biological barrier resistance. Food Research International. 2003;36[9]:895-904.

45. Siró I. Challenges of Beneficial Health Claims. In: Liong M-T, editor. Probiotics: Biology, Genetics and Health Aspects. Berlin, Heidelberg: Springer Berlin Heidelberg; 2011. p. 243-68.

46. Bedani R, Rossi EA, Isay Saad SM. Impact of inulin and okara on Lactobacillus acidophilus La-5 and Bifidobacterium animalis Bb-12 viability in a fermented soy product and probiotic survival under in vitro simulated gastrointestinal conditions. Food Microbiology. 2013;34[2]:382-9.

47. Burns P, Lafferriere L, Vinderola G, Reinheimer J. Influence of dairy practices on the capacity of probiotic bacteria to overcome simulated gastric digestion. International Journal of Dairy Technology. 2014;67[3]:448-57.

48. Casarotti SN, Todorov SD, Penna ALB. Effect of different matrices on probiotic resistance to in vitro simulated gastrointestinal conditions. International Journal of Dairy Technology. 2015;68[4]:595-601.

49. Sendra E, Sayas-Barberá ME, Fernández-López J, Pérez-Alvarez JA. Effect of food composition on probiotic bacteria viability. In: Watson RR, Victor R. Preedy, editors. Probiotics, Prebiotics, and Synbiotics. London, UK: Elsevier; 2016. p. 257-69.

50. Begley M, Gahan CGM, Hill C. The interaction between bacteria and bile. FEMS Microbiology Reviews. 2005;29[4]:625-51.

51. Canzi E, Guglielmetti S, Mora D, Tamagnini I, Parini C. Conditions affecting cell surface properties of human intestinal bifidobacteria. Antonie Van Leeuwenhoek. 2005;88[3-4]:207-19.

52. Dianawati D, Mishra V, Shah NP. Survival of microencapsulated probiotic bacteria after processing and during storage: A review. Critical Reviews in Food Science and Nutrition. 2015;56[October]:1685-716.

53. Wang L-Q, Meng X-C, Zhang B-R, Wang Y, Shang Y-L. Influence of cell surface properties on adhesion ability of bifidobacteria. World Journal of Microbiology and Biotechnology. 2010;26[11]:1999-2007.

54. Lee B, Yin X, Griffey SM, Marco ML. Attenuation of colitis by Lactobacillus casei BL23 is dependent on the dairy delivery matrix. Applied and Environmental Microbiology. 2015;81[18]:6425-35.

55. Failla ML, Chitchumroonchokchai C. In vitro models as tools for screening the relative bioavailabilities of provitamin A carotenoids in foods. Washington, DC: HarvestPlus; 2005. 36 p.

56. Gebara C, Chaves KS, Ribeiro MCE, Souza FN, Grosso CRF, Gigante ML. Viability of Lactobacillus acidophilus La5 in pectin-whey protein microparticles during exposure to simulated gastrointestinal conditions. Food Research International. 2013;51[2]:872-8.

57. Krasaekoopt W, Watcharapoka S. Effect of addition of inulin and galactooligosaccharide on the survival of microencapsulated probiotics in alginate beads coated with chitosan in simulated digestive system, yogurt and fruit juice. LWT - Food Science and Technology. 2014;57[2]:761-6.

58. Maciel GM, Chaves KS, Grosso CRF, Gigante ML. Microencapsulation of Lactobacillus acidophilus La-5 by spray-drying using sweet whey and skim milk as encapsulating materials. Journal of Dairy Science. 2014;97[4]:1991-8.

59. Yonekura L, Sun H, Soukoulis C, Fisk I. Microencapsulation of
Lactobacillus acidophilus NCIMB 701748 in matrices containing soluble fibre by spray drying: Technological characterization, storage stability and survival after in vitro digestion. Journal of Functional Foods. 2014;6[1]:205-14

60. Chiu Y-H, Lin S-L, Tsai J-J, Lin M-Y. Probiotic actions on diseases: implications for therapeutic treatments. Food and Function. 2014;5[4]:625-34.

61. Pinto SS, Verruck S, Vieira CRW, Prudêncio ES, Amante ER, Amboni RDMC. Influence of microencapsulation with sweet whey and prebiotics on the survival of Bifidobacterium-BB-12 under simulated gastrointestinal conditions and heat treatments. LWT - Food Science and Technology. 2015;64[2]:1004-9.

62. de Almeida J dos SO, Dias CO, Pinto SS, Pereira LC, Verruck S, Fritzen-Freire CB, et al. Probiotic Mascarpone-type cheese: Characterisation and cell viability during storage and simulated gastrointestinal conditions. International Journal of Dairy Technology. 2018;71:195-203.

63. Pinto SS, Cavalcante BD, Verruck S, Alves LF, Prudêncio ES, Amboni RD. Effect of the incorporation of Bifidobacterium BB-12 microencapsulated with sweet whey and inulin on the properties of Greek-style yogurt. Journal of Food Science and Technology. 2017;54[9]:2804-13

64. Ferreira CLLF. Benefícios das culturas lácticas probióticas. In: Oliveira M, editor. Tecnologia de Produtos Lácteos Funcionais. São Paulo, SP: Atheneu; 2009. p. 213-34

65. Makras L, De Vuyst L. The in vitro inhibition of Gram-negative pathogenic bacteria by bifidobacteria is caused by the production of organic acids. International Dairy Journal. 2006;16[9]:1049-57.

66. Martinez FAC, Balciunas EM, Converti A, Cotter PD, de Souza Oliveira RP. Bacteriocin production by Bifidobacterium spp. A review. Biotechnology Advances. 2013;31[4]:482-8.

67. Ennahar S, Sashihara T, Sonomoto K, Ishizaki A. Class lla bacteriocins: biosynthesis, structure and activity. FEMS Microbiology Reviews. 2000;24[1]:85-106.

68. Lima ET, Andreatti Filho RL, Okamoto AS, Noujaim JC, Barros MR, Crocci AJ. Evaluation in vitro of the antagonistic substances produced by Lactobacillus spp. isolated from chickens. Canadian Journal of Veterinary Research. 2007;71[2]:103-7

69. Hutt P, Shchepetova J, Loivukene K, Kullisaar T, Mikelsaar M. Antagonistic activity of probiotic lactobacilli and bifidobacteria against entero- and uropathogens. Journal of Applied Microbiology. 2006;100[6]:1324-32.

70. Gibson GR, Wang X. Regulatory effects of bifidobacteria on the growth of other colonic bacteria. Journal of Applied Bacteriology. 1994;77[4]:412-20.

71. Martins FS, Silva AA, Vieira AT, Barbosa FHF, Arantes RME, Teixeira MM, et al. Comparative study of Bifidobacterium animalis, Escherichia coli, Lactobacillus casei and Saccharomyces boulardii probiotic properties. Archives of Microbiology. 2009;191[8]:623-30.

72. Saleh FA, El-Sayed EM. Isolation and characterization of bacteriocins produced by Bifidobacterium lactis BB-12 and Bifidobacterium longum BB-46. In: 9 $9^{\text {th }}$ Egyptian Conference for Dairy Science and Technology [Internet]. Cairo: Research Papers; 2004. p. 323-37.

73. Collado MC, Grze-kowiak $Ł$, Salminen S. Probiotic Strains and Their Combination inhibit in vitro adhesion of pathogens to pig intestinal mucosa. Current Microbiology. 2007;55[3]:260-5.

74. Bernet MF, Brassart D, Neeser JR, Servin AL. Adhesion of human bifidobacterial strains to cultured human intestinal epithelial cells and inhibition of enteropathogen-cell interactions. Applied and Environmental Microbiology. 1993;59[12]:4121-8.

75. Collado MC, Meriluoto J, Salminen S. Role of commercial probiotic strains against human pathogen adhesion to intestinal mucus. Letters in Applied Microbiology. 2007;45[4]:454-60.

76. O'Sullivan D. Bifidobacteria and siderophores produced thereby and methods of use. Google Patents; US20020058326A1, 2002.

77. Deriu E, Liu JZ, Pezeshki M, Edwards RA, Ochoa RJ, Contreras H, et al. Probiotic bacteria reduce salmonella typhimurium intestinal colonization by competing for iron. Cell Host Microbe. 2013;14[1]:26-37.

78. Weiss G. Intestinal irony: how probiotic bacteria outcompete bad bugs. Cell Host Microbe. 2013;14[1]:3-4.

79. Vazquez-Gutierrez P, Lacroix C, Jaeggi T, Zeder C, Zimmerman M Chassard C. Bifidobacteria strains isolated from stools of iron deficient infants can efficiently sequester iron. BMC Microbiology. $2015 ; 15[1]: 3$ 